World Health Organisation Expert Committee on Rabies. Seventh report. Geneva: World Health Organisation, 1984. (Technical Report Series No 709 .

4 Wiktor TJ, Fernandes MV, Koprowski $H$. Cultivation of rabies virus in human diploid cell strain W1-38. F Immunol 1964;93:353-66.

Aoki FY, Tyrrell DAJ, Hill LE, Turner GS. Immunogenicity and acceptability of a human diploid cell culture rabies vaccine in volunteers. Lancet 1975;i:660-2.

Bahmanyar M. Results of antibody profiles in man vaccinated with various schedules. Symposium Series on Immunobiological Standardisation 1974;21:231-9.

7 Bahmanyar M, Fayaz A, Nour-Salehi S, Mohammadi M, Koprowski H. Successful protection of humans exposed to rabies infection. Post-exposure treatment with the new human diploid cell rabies vaccine and anti-rabies serum. FAMA 1976;236:2751-4.

8 Devriendt J, Staroukine $M$, Costy F, Vanderhaeghen J-J. Fatal encephalitis apparently due to rabies. Occurrence after treatment with human diploid cell vaccine but not rabies immune globulin. FAMA 1982;248:2304-6.

Wattanasri S, Boonthai P, Thongcharoen P. Human rabies after late administration of human diploid cell vaccine without hyperimmune serum. Lancet 1982;ii:870.

10 Gardner SD. Prevention of rabies in man in England and Wales. In: Pattison JR, ed. Rabies a growing threat. Wokingham: van Nostrand Reinhold, 1983:39-49.

11 Anonymous. Systemic allergic reactions following immunization with human diploid cell rabies vaccine. MMWR 1984;33:185-7.

12 Boe $\mathrm{E}$, Nyland $\mathrm{H}$. Guillain-Barré syndrome after vaccination with human diploid cell rabies vaccine Scand Infect Dis 1980;12:231-2.

vaccine. Scand $\mathcal{F}$ Infect Dis $1980 ; 12: 231-2$.
Bernard KW, Smith PW, Kader FJ, Moran

, Smith PW, Kader FJ, Moran MJ. Neuroparalytic illness and human diploid cell 982;248:3136-8

4 Warrell MJ, Suntharasamai P, Nicholson KG et al. Multisite intradermal and multisite subcutaneous rabies vaccination: improved economical regimens. Lancet 1984;i:874-6.

15 Atanasiu P, Perrin P, Segre L, Manganas O. Evaluation and comparative studies of inactivated rabies vaccines obtained in the heterologous diploid and polyploid cells (HAK, BHK and Vero). Developments in Biological Standardization 1982;50:173-82

16 Berlin BS, Mitchell JR, Burgoyne GH, Brown WE, Goswick C. Rhesus diploid rabies vaccine (adsorbed) a new rabies vaccine. Results of clinical studies simulating prophylactic therapy for rabies exposure. FAMA 1983;249:2663-5.

7 Barth $\mathrm{R}$, Gruschkau $\mathrm{H}$, Bijok $\mathrm{U}$, et al. A new inactivated tissue culture rabies vaccine for use in man. Evaluation of PCEC-vaccine by laboratory tests. F Biol Stand 1984;12:29-46.

18 Suntharasamai $\mathrm{P}$, Chanthavanich $\mathrm{P}$. Warrell $\mathrm{MJ}$, et al. Purified vero cell rabies vaccine and human cell strain vaccine: comparison of neutralising antibody responses to post-exposure regimens. fHyg 1986;96:483-9.

19 Roumiantzeff M, Ajian N, Branche R. et al. Rabies vaccine produced in cell culture: production control and clinical results. In: Kurstak E, ed. Applied virology. London: Academic Press, 1984:241-96.

20 Lecocq JP, Kieny MP, Lemoine Y, et al. New rabies vaccines: recombinant DNA approaches. In: Koprowski H, Plotkin SA, eds. World's debt to Pasteur. New York: Alan R Liss, 1985:259-71.

21 World Health Organisation Collaborating Centre for Rabies Surveillance and Research, Tuebingen, Federal Republic of Germany. Information on bat rabies in Europe. Rabies Bulletin Europe 1986;10:11-2(Ab 1/86)

\section{Why nursing education has to change}

Florence Nightingale said that "Reports are not selfexecutive," and nothing could be more true of the many reports on nursing education. The past 50 years have seen at least six-Athlone (1938), Horder (1943), Wood (1947), Platt (1964), Briggs (1972), and Judge (1985). All made remarkably similar recommendations, and none was implemented (apart from small changes at the margins). To expect too much from the latest report-Project 2000: A New Preparation for Practice-would thus be (in Oscar Wilde's words) a "triumph of optimism over experience."

But Project 2000 is different. Firstly, all sections of the nursing profession (a group not noted for its unity) appear to agree for the first time not only on the need for change but also on its key components. Secondly, the case for change this time supports the self interest of the service providers as well as the aspirations of nursing visionaries. Thirdly, the proposals come from the body that has the legal responsibility for establishing and improving the standards of training and practice of nurses; it thus has the power to implement its proposals.

Project 2000 has come from the United Kingdom Central Council for Nursing, Midwifery, and Health Visiting, the statutory body formed in 1979 by the amalgamation of all the bodies previously responsible for the education and regulation of the three parts of the nursing profession. It describes the changes needed in the training of nurses, midwives, and health visitors to enable them to meet the needs of the 1990s and beyond. The council also states its perceptions of the roles and responsibilities of nurses. Although Project 2000 is a consultation document addressed primarily to nurses, there is no doubt about the council's commitment to change or about its main direction.

The proposals are radical, and the aim is to produce a registered practitioner (the word practitioner is used as shorthand for the cumbersome specification of the three separate parts of the nursing profession) who is competent to assess nursing needs, provide nursing care, and monitor and evaluate the care given. She is to be a "knowledgeable doer" with analytical as well as technical skills, capable of autonomous practice, and fully accountable for her decisions. A new aim is that she should be able to practise at this basic level in both institutions and the community.

The core recommendation-for a two year common foundation course followed by one year's specialisation - is a reasonable compromise between the "genericists" and those who have advocated direct entry into the specialties. It will provide a sound basis for the later training needed by new specialist practitioners, who will be the future ward sisters, team leaders, teacher practitioners, and clinical managers. This is the beginnings, at last, of a clinical career structure. There is a clear commitment to preparing nurses who will nurse-in contrast to the position now, when patients are nursed (at least in hospitals) by unqualified auxiliaries and unskilled neophytes while the qualified nurses merely supervise.

The key change here-one advocated by every review of nursing education since the $40 \mathrm{~s}-$ is an end to the dependence of the hospital services on student labour. Separation of the funding of education from the service budget and removal of the students from the staff establishment will enable the student's clinical experience to be based on learning needs rather than the exigencies of the service. The education will become much broader, more community orientated, and based on a health orientated nursing model instead of the disease orientated medical model, which, quite properly, dominates medical practice. Those who once believed that hospitals could not survive without student labour now realise not only that students are no longer cheap (already only about $20 \%$ of their paid time is spent providing service) but also that an ever changing, unpredictable, and unskilled workforce is wasteful. Project 2000 may succeed where its predecessors failed simply because this time the costs of doing nothing are greater than the price of change.

JUNE CLARK

Special Projects and Community Nursing Officer,

Lewisham and North Southwark Health Authority, London SE1 9RT

\section{Blood transfusions and cancer: anomalies explained?}

Had we the ancients' respect for blood we should not think of a tranfusion as the mere replenishment of oxygen carrying capacity. We can assemble an impressive series of the unexpected consequences of transfusing blood. Older rheumatologists tell of remissions in rheumatoid arthritis begun by blood transfusion. ${ }^{1}$ Recently spontaneous abortion has been shown to be preventable in some cases by a transfusion of husband's blood. ${ }^{2}$ The effect of blood transfusion on renal allografts has been disputed ever since 1973, when Opelz and Teraski ${ }^{3}$ suggested, to much scepticism, 